\title{
Protection of Human Rights and the Role of the Albanian Rule of Law in their Respect and Implementation, Particularly in the Right to Fair Trial
}

\author{
PhD Candidate Ina Foto Barjamaj
}

\author{
Prof. Dr. Alba Robert Dumi
}

\begin{abstract}
${ }_{1}$ PhD student at Institute of Europe, University of Tirana, Permbaruese Gjyqesore Private; Email: ina.puravelli@yahoo.com 2Director of Graduate School, "Ismail Qemali" Vlore University, Albania, Business Department 2 Economy Faculty Tirana Business Department; Email:alba.besi12@gmail.com
\end{abstract}

\author{
Doi:10.5901/ajis.2015.v4n3s1p54
}

\section{Abstract}

This paper reflects a picture of the legal changes that have occurred in Albanian state, the reforms that have been under taken in law and in particular in the field of human rights. The establishment of democracy has required fundamental changes not only in recognition of the rights and fundamental freedoms, but also the sanction of real guarantees for the protection and enforcement of these rights, without the existence of these guarantees, the recognizing would not have any value and would be utopia. Issues raised for discussion in this paper are: Protection of human rights in democracy and their implementation. Guarantees that the Albanian Constitution provides for the recognition and protection of human rights. The role of law enforcement bodies in the implementation of protective mechanisms and in particular the justice system to ensure respect for the right to due judicial process. Through analysis of the legal and judicial practice in the field of protection of human rights, we aim to bring out the challenges faced by the Albanian institutions, whether nationally as well as internationally. A state that respects and protects human values testifies a healthy society that has consolidated basis and that stimulates economic, social and cultural prosperity.

Keywords: change, democracy, reform, pluralism, protection of fundamental rights and human freedoms, the right to due judicial process.

\section{Introduction}

After a long period of complete isolation, Albanians felt the need to change the governance system transitioning to a new democratic system. Student Movement of December 1990 the first protest began as a termination of electricity, to the difficult economic conditions in those moments was Albania, as well as the very difficult conditions that have students in dormitories and schools. In addition to meeting the requirements for living conditions later they asked permission of pluralism accompanied by the phrase "We want Albania like Europe". This movement had a hidden dream of many Albanians. The arrival of democracy together with very good also brought a lot of chaos and disorientation. Disorientation reasons are unknown. Here begins the gray areas termed as the Albanian transition, which is more like a long calvary that tired mostly Albanian people in achieving those standards necessary for a European country. The process of "transition" should be a normal process through which we must pass to consolidate democratic model. Opening the borders resulted in a large influx of immigrants, which in search of a better economic life were willing to sacrifice everything, those few savings income. Democracy brought a new era brought political pluralism and the development of the first elections free. But it didn't encourage the desire to work and to develop the enterprises that Albanian state already possessed. Labor shortages brought economic decline of Albanians, who saw emigration as the only solution. No doubt that these developments were also reflected in political and social life. The democratic changes that occurred in the early 90s marked important turning point in the history of the Albanian state and its institutions. Democracy can come in different ways, in different contexts, but never comes easily. Democratic orientation requires the performing of a deep institutional reform, which should give way eventually to democratic transformations for the construction of the rule of law and respect for human rights. The basic principles that led the democratic changes in the law was originally announced in the law number 7491 date.29.04.1991 "For the main constitutional provisions", then in the law nr.7561 date.29.04.1992 "On amendments and additions to Law No. 7491 date 29.04.1991 "On the main constitutional provisions". 


\section{The Notion of Rights and Fundamental Freedoms in Albania}

"All men are created equal; Creator has endowed them with certain unalienable rights, in which part of the right to life, the right to freedom and the right to be in search of happiness. To secure these rights, people form governments, whose power derives from the consent to give her the governed. "

Unalienable rights include freedom of speech and expression, freedom of religion and conscience, freedom of assembly and the right to equal protection before the law. This is not the whole list of rights that citizens enjoy in a democratic state. Democratic societies also protect the civil rights such as the right to fair trial. However the above rights constitute essential rights that should protect a democratic government. The democratic government is formed to protect these rights that every individual enjoy by virtue of his existence. The universal principles of democracy are: majority rule and respect for minority, restricted government by the constitution, respect for human rights and the sovereignty of law. The rights and freedoms are criterion and fundamental measure for the position and role of man and citizen in society, on one hand and for the democratization of the system, on the other. They are an instrument for limiting the power and prevent arbitrariness and bad usage of power. Every democratic society has the duty of building the constitutional, legal and social, to ensure the protection of these rights.

These principles are embodied in the Constitution of the Republic of Albania. The rights and freedoms are fundamental value of the constitutional order, which in its preamble states: "to guarantee the rights and fundamental freedoms in the spirit of tolerance and religious coexistence, with the commitment to protect the dignity and human personality ${ }^{1 "}$, making it an integral part of these commitments. The Constitution lists a number of rights which must be guaranteed, as individual rights, freedoms and political rights as well as economic, social and cultural. In addition to an extensive catalog of human rights and fundamental freedoms, The Constitution has given priority to international instruments on human rights facing the domestic legal order, in case of conflict. The Constitution specifies that the rights may be limited even when they are absolute. Moreover, it identified those institutions such as the courts and the ombudsman, who will be responsible for the implementation of human rights.

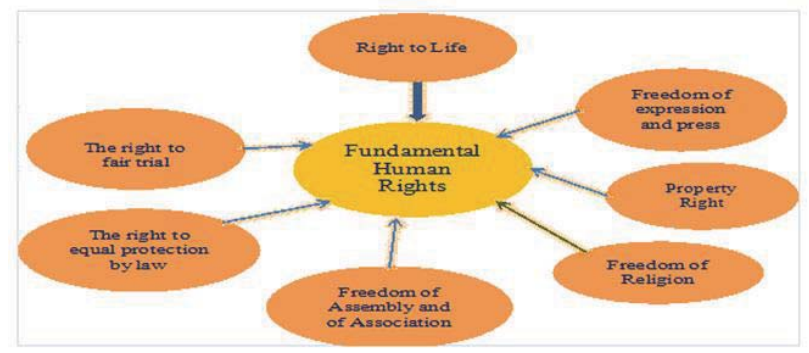

\section{Recognition and the Importance of Protecting Human Rights}

The degree of emancipation and development of a society depends on respecting and enforcement of individual rights and the rule of law. The affirmation of the right would be a formality if there are no security mechanisms for their implementation. Only human beings who understand human rights can work to secure and protect them from themselves and from the others. To do this it is necessary to be informed. Effective education for human rights has two fundamental goals: teaching about human rights and teaching for the human rights. Only by respecting the principles of human rights, our lives may present the foundations for coexistence and respect of the rights of others.

Legal protection of human rights and fundamental freedoms. We distinguish two types of legal protection of the rights and freedoms of man and citizen: internal and external. Internal protection shall be realized through positive law in the country, while the second (external) with the help of international law. There are different forms of protection of freedoms and judicial rights as the basic form, the ombudsman as an organ for the protection of human rights and freedoms when they are violated by the state administration bodies, protection from common courts, and protection from the Constitutional Court. Ombudsman's Office, as governmental bodies of human rights is the main institution for the 
promotion and implementation of human rights. The Ombudsman has the authority to inspect preventive detention facilities and prisons and to initiate cases where the victim cannot come themselves. The Ombudsman acts as a monitor for violations of human rights and reports to Parliament once a year.

The Parliament has a committee for the legal affairs, public administration and human rights. Cases of discrimination can be brought before the government commissioner against discrimination issues. However, the office of the Commissioner was focused mainly on support and awareness campaigns put very few sanctions against government officials ${ }^{2}$. Anti-discrimination law allows the commissioner to testify as a witness in the appeals issues, that the Office has refused. Two issues were presented to the court that tested the application of the law. The court ruled that there had been discrimination in one case, which was an appeal by the end of the year, and by October the court had not taken any decision for the second.

International protection of human rights and freedoms flows through observation and control, as well as through sanctions against countries - member states to the UN in case of wide and heavy violation of the human rights and freedoms. Besides the United Nations system, to protect these rights there is the Council of Europe system, which has its source in two treaties:

European Convention of Human Rights and the European Social Charter. The first serves as a basic document for the decisions taken by one of the most important European institutions with the role it plays as a judicial body in conflicts between states, and even in conflicts between states and individuals. Of course we are talking about the European Court of Human Rights.

Since Albania's adherence to the European Court of Human Rights, the Albanian citizens were given the opportunity to access for the different violations, which they claim for not respecting from the national authorities. About 230 issues are under review against Albania in this Court. Most of them related to the infringement of property rights or the principle of fair trial, due to non-execution of court decisions final.

\section{The Right to a Fair Trial as Constitutional Right}

Human rights are different and change their nature. One of the most basic rights that is provided for in Article 42 of the Constitution is the right to a fair trial. The right to fair hearing is constitutional right of individuals, through which they seek implementation of procedures and fair legal rights. On the one hand, this constitutional right is presented as a guarantee for the citizens against unjust actions of state authorities and, on the other hand, it is an obligation for the latter not to infringe the rights and freedoms of citizens without providing them with respecting regular legal procedures.

European Convention for the Protection of Human Rights and Fundamental Freedoms in its Article 6, entitled "The right to fair trial", has sanctioned the right of citizens to be heard fairly, publicly and within a reasonable time by an independent court and impartial tribunal established by law - as one of the fundamental rights of citizens.

In the Constitution of Republic of Albania, the right for the fair legal process specifically is mentioned in her two articles. Article 42 of the constitution rule this right in addition to the rights and freedoms of citizens, while Article 131 letter "f" determines it as a matter of jurisdiction for the Constitutional Court. In both provisions this important principle appears as constitutional guarantee to every deprivation that the state through its decision-making bodies can violate the basic right of individuals. Article 42 of the Constitution sanctions the protection of all the rights recognized in the Constitution and the law, highlighting as main rights freedom, the right to property, which can be restricted if is applied the necessary condition of respecting the legal process, only in this case may be permitted the constitutional limitations. What the Constitution does not give, it is trying to solve the practice of the Constitutional Court, which is typically oriented the jurisprudence of the European Court of Human Rights and of several other European constitutional courts. The Constitutional Court has attempted in its case to make a substantial difference to its role as the authority that guarantees respect for the Constitution, the function of giving justice which is an attribute of judicial power bodies. The execution of court decisions is an important element of the right to a fair trial, because a right acquired remains worthless unless implemented through the execution of the decision ${ }^{3}$. The execution of a final decision of the court is considered as the final stages of law enforcement. Only after completion of this phase can be considered that the individual has fully established its right 4 .

\footnotetext{
${ }^{2}$ Executive Summary of the Annual Report on Human Rights of the US Department of State

${ }^{3}$ The decision of the Constitutional Court of the Republic of Albania no. 49, dated 21.11.2011

${ }^{4}$ The decision of the Constitutional Court of the Republic of Albania no. 11, dated 03.02.2012 


\section{Cases of Judicial Practice of the European Court for Fair Trial Against the Albanian State}

States have an obligation to execute the decisions of the European Court of human rights occur as liability arising from the ratification of the European Convention of human rights. European Convention addresses to the institutions and organs of the EU and Member States (Article 51 (1)) only when they are "applying" the right of EU. This general obligation creates other special obligations, namely the obligation to execute the obligation breached, to end the international wrong act, to repair and to prevent similar violations in the future; all these measures imply the adoption of special and general measures.

The European Court was set up in order to "ensure the observance of the commitments undertaken by the High Contracting Parties in the present Convention" (former Article 19).

These commitments include the undertaking to "abide by the final judgment of the Court in any case to which are parties". Court's jurisprudence covers a wide range of issues, based on individual applications and restricted to specific problems raised by applicants.

Article 6 of the European Convention on Human Rights (ECHR) guarantees the right to a fair trial in both civil and criminal proceedings. This has been interpreted as providing for a general requirement of some measure of "equality of arms" between the state and the individual or between the parties in the case.

According to her, the exhaustion of domestic remedies is not absolute and cannot be applied either automatically ${ }^{5}$. An application may be submitted by either Contracting State (State application) or any individual who claims to be victim of a violation of the rights represented by the Convention and Protocols.

The right to a fair trial ultimately does not only involve the acceptance and progress of the process, but also the execution of the decision ${ }^{6}$. Execution of the judgment is considered to be an integral part of the fundamental human right to a fair trial. The Court has its own mechanism to protect human rights but don't have jurisdiction to re-open domestic legal proceedings or to substitute the decision given by the domestic courts.

The European Court has delivered 6 judgments in 2014, concerning Albania, which found at least one violation of the European Convention on Human Rights.

The European Court, in a decision dated November 18, 2004 Qufaj Co against Albania, number. 54268/00, addressed the issue of non-enforcement of court decisions in Albania. In this case, the Municipality of Tirana had granted permission to a company for a building, but no construction permit for some residential apartments. As a result of significant losses in its commercial activities, the company sued the Municipality of Tirana in Tirana District Court seeking a compensation of 60 million leke. After the rejection of the request by the court, the company appealed to the Court of Appeal which ordered the Municipality of Tirana to pay the company the amount $60,000,000$ ALL. As a result of the absence of recourse to the Supreme Court, the above mentioned decision became final. Since this decision was not executed, the company complained to the Constitutional Court which rejected the request on the grounds that the execution of court decisions was outside its competence. Delays in execution of a decision cannot be justified if it is detrimental to the essence of the right protected in the sense of Article $6 \S 1$ of the Convention.

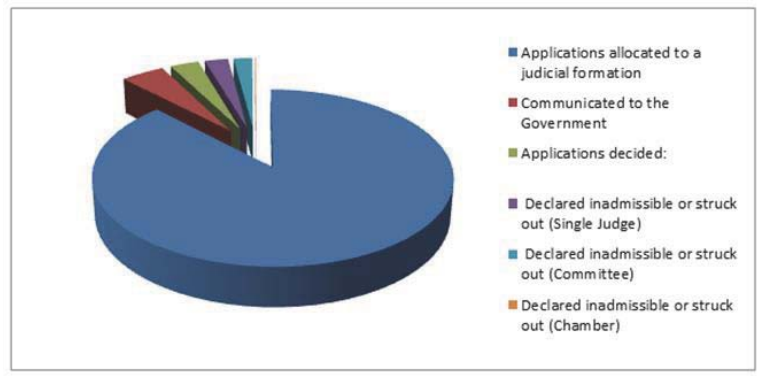

The information of this table about the applications to the Court was taken by the internet site of ECHR ${ }^{7}$

\footnotetext{
${ }^{5}$ Akdivar and Others versus Turkey, judgment of 09.16.1996

${ }^{6}$ Quote from the European Court for the Protection of Human Rights is the 1997 case of Hornsby against Greece

${ }^{7}$ http://www.echr.coe.int/Documents/CP_Albania_ENG.pdf, visited on date 30.07.2015 
In another case Driza against Albania, The Court notes that, as in the decision Beshiri8, authorities did not offer to the applicant the opportunity to receive appropriate compensation in accordance with the previous decision of the court of final. These facts are sufficient to enable the Court to conclude that the failure of the measures necessary to execute the final decision ${ }^{9}$, the upload Albanian authorities with responsibility for non-compliance of Article $6 \S 1$ of the Convention.

In another case, Gjyli against Albania, the European Court notes that the domestic decisions of the Constitutional Court determine that there is a violation of decisions of domestic courts. However their findings were declaratory, so the Constitutional Court did not provide any adequate reparation. Furthermore it does not make any compensation for damages and immaterial material, and nor could it offered a clear perspective to prevent the violation claimed ${ }^{10}$.

So far the ECtHR decisions, should serve as encouragement for the execution of judgments of the Constitutional Court, with the object of finding a violation of due legal process in order to avoid as much as possible of the Albanian state financial punishment by the ECtHR. From the above analysis of the issues subject to a finding of violation of due legal process due to non-execution of final court decisions, will suggest changes in the organic law of the Constitutional Court, determination of rules that define a complete and clear compensation for individuals in case of finding a violation of their rights. The creation of a special monitoring body for the execution of the decisions of this nature, but also other decisions that can display non-execution problem.

\section{Challenges Facing the Albanian Society in the Field of Human Rights and the Improvement that are Made in this Field}

Over the last decade, Albania has made significant progress in the development and approval of laws which are in accordance with international standards of human rights and the Acque comunitare, but there are still problems in their implementation. The legal infrastructure is generally in compliance with the European and international standards, but still has a problem in its application in practice. This is due to the lack of human and financial resources, lack of professional expertise and sometimes administrative obstacles due to lack of political will on the other side .The effective implementation of laws requires greater financial support, human resources with sufficient expertise professional as well as greater efforts in coordination, cooperation and information sharing between key actors who are responsible for drafting and implementing laws. Effective implementations of laws reflect the effective implementation of human rights. The issue of implementation of relevant human rights and is conditional upon the effective implementation of laws. In general, poor implementation of laws is the major obstacle to the protection, promotion and enforcement of human rights. Other problems of human rights during the past year included several cases of physical mistreatment in police detention centers, domestic violence and discrimination against women and children, abuses and discrimination based on ethnic minority status and sexual orientation or gender identity. There were also reports of trafficking in persons cases. The government has not always taken steps to prosecute officials who committed abuses. Many government officials enjoyed immunity from prosecution, while those who had powerful business interests were often able to avoid prosecution. The reasons that are behind this situation should be clearly understood and required a commitment to to be improving in the future.

The guarantee of rights and freedoms, recognized in the Constitution, and the forecast of measures to put them in should be aimed at improving and enhancing human rights standards (see decisions no. 31, dated 18.06.2010, No. 9 dated 26.02.2007, No. 34 dated 20.12.2005 of the Constitutional Court). The legislator can not unreasonably worsen the legal situation of individuals, to deny the rights acquired or to ignore their legitimate interests. To really understand and apply this principle is required, on one hand, that the law in a society to provide security, clarity and continuity, so that the individuals direct their actions in the correct order and in accordance with and on the another hand, that the law itself can't remain static if necessary to shape a concept, such as that of justice, in a rapidly changing society (see decision no. 36 dated 15.10.2007 of the Constitutional Court). In addition, consistent with the premise that the Convention is a living instrument, the Court's Article 6 jurisprudence has developed progressively over the years to encompass an ever increasing variety of legal proceedings.

The Court reiterates that this principle cannot prevail in any case. This means that if there is a case of a different

${ }^{8}$ Beshiri and other against Albania, 22 August 2007 (Applocation no. 7352/03)

${ }^{9}$ Driza and other against Albania, 17 November 2007 (Application no.33771/02) The Court finds that this problem persists despite the conclusions given in Qufaj Co. sh.p.k and Beshiri.

10 Gjyli against Albania, paragraph 58 
legal regulation of a relationship which is directly affected by the public interest, with all its essential elements, such interest, naturally, will prevail over the principle of legal certainty (see Decision no. 26, dated 02.11.2005 of the Constitutional Court).

Albanian Parliament after the democratic changes approved a set of laws, with the aim of repairing the injustices inherited from the previous regime, regarding the guarantee of human rights and fundamental freedoms, particularly the right to private property. Strands of legislation are laws 7652, dated 23.12.1992 "On privatization of state housing" and law No. 7698, dated 15.04.1993 "On restitution and compensation of property to former owners."

Rights in general are closely related with essential changes in the system of governance of a state, it is the transition from totalitarian to a democratic regime and reforms in the political, legal and economic ${ }^{11}$. Social rights distinguish by social objectives, as these are the ultimate expression of state goals and principles of its policy designed to guide the activity in general and, especially, social policy ${ }^{12}$.

Albania, as a NATO member and EU candidate strongly supports the respect of human rights and their universality. Albania's membership in the Council of Human Rights of the UN is first of all a responsibility for further democratization of our society. This membership is also an expression of our achievements in the area of freedom and democracy that almost a quarter-century ago, seemed impossible.

\section{Conclusions}

Democracy can come in different ways, in different contexts, but never comes easily. State democratic orientation require performing a deep institutional reform, which should open the way to democratic transformations for the construction of the rule of law and respect for human rights.

Over the last decade, Albania has made significant progress in the development and approval of laws which are inconsistent with international standards of human rights and the Acque comunitare, but still has a problem in its application in practice. This is due to the lack of human and financial resources, lack of professional expertise and sometimes administrative obstacles due to lack of political will. In a great number of cases are seen lack of enforcement of final court decisions, citing cases Gjyli, Driza or Beshiri against Albania, for this reason the European Court in this cases found violation of the rights of the European Convention and punish the Albanian state.

\section{Recommendations}

The reasons that are behind this situation should be clearly understood and required a commitment to shape the future. In the framework of one of the fundamental human rights, the right to fair trial, would recommend changes in the organic law of the Constitutional Court rules that determine the full and clear that give her the right to reparations for assignment finding individuals in cases of violation of their rights. The creation of a special body monitoring the execution of the decisions of this nature, but also other decisions that may show non-execution problem. Albania needs to find people who have real managerial skills.

\section{References}

\section{The Constitution of the Republic of Albania}

European Convention for the Protection of Human Rights and Fundamental Freedoms

Law Nr.9359, dated 24.03.2005 "On accession of the Republic of Albania to the Convention" On relations with children ";

Law nr.9443, dated 16.11.2005 "On accession of the Republic of Albania to the Convention" On jurisdiction, applicable law, recognition, enforcement and cooperation in respect of parental responsibility and measures for the protection of children ";

Law no. 9446, dated 24.11.2005 "On accession of the Republic of Albania to the Convention" On civil aspects of international child abduction"

Law no. 8137, dated 31.07.1996 "On the ratification of the European Convention" On Protection of Rights and Fundamental Freedoms "; Qufaj Co. against Albania, 18 November 2004 (Application no. 54268/00)

Gjyli against Albania, September 29, 2009, App. 32907/07.

Driza and other against Albania, 17 November 2007 (Application no.33771/02)

11 The decision of the ECHR in the case "Maria Atanasiu and others against Romania ", dated 12.01.2011

12 Decision no. 34 dated 28.05.2012 Constitutional Court 
Beshiri and other against Albania, 22 August 2007 (Application no. 7352/03)

The decision of the ECHR in the case "Maria Atanasiu and others against Romania ", dated 12.01.2011

Decision no. 34 dated 28.05.2012 Constitutional Court

Akdivar and Others versus Turkey, judgment of 09.16.1996

Executive Summary of the Annual Report on Human Rights of the US Department of State

Quote from the European Court for the Protection of Human Rights is the 1997 case of Hornsby against Greece

http://www.echr.coe.int/Documents/CP_Albania_ENG.pdf, visited on date 30.07.2015

Barkhuysen Tom and Van Emmerik Michiel, 'A comparative view on the execution of the judgments of the European Court of Human Rights.

The decision of the Constitutional Court of the Republic of Albania no. 49, dated 21.11.2011.

The decision of the Constitutional Court of the Republic of Albania no. 11, dated 03.02.2012.

The execution of judgments of the European Court of Human Rights, Elisabeth Lambert-Abdelgawad

Chercheur au CNRS,UMR de droit comparé de Paris (Paris I-CNRS) 2002 page 26-28. 